\title{
Determinants of Corporate Liquidity - An Analysis of Cash Holdings
}

\author{
${ }^{1}$ Sara Anjum, ${ }^{2}$ Qaisar Ali Malik \\ ${ }^{I}$ FUIRC, Department of Business \& Economics. \\ ${ }^{2}$ Assistant Professor, FUIRC, Department of Business \& Economics.
}

\begin{abstract}
The objective of the study is to determine and measure how and to what extent size of the firm, net working capital, leverage, cash conversion cycle and sales growth affect the cash holdings of corporate organizations. The study selected 395 non financial companies of Pakistan listed on Karachi stock exchange, for the purpose of examining the relationships. Financial data for 6 years period was included in analysis covering years 2005-2011. Descriptive statistics, Pearson correlation, multiple regression and ANOVA were used to conduct the analysis. The results demonstrated significant relationship between cash holdings and the selected variables except sales growth. This study will contribute in understanding the factors affecting corporate liquidity by financial managers as well as the investors seeking to invest in Pakistani companies.

Keywords: Cash Holdings, Firm Size, Leverage, Net Working Capital, Sales Growth, Cash Conversion Cycle
\end{abstract}

\section{Introduction}

It is generally observed that companies having high investment opportunities in capital markets and also having higher credit ratings have lesser level of cash balances as compared to noncash assets or balances then companies with less investment opportunities. Yet literature have provided evidence where many of the high credit rating companies accumulated higher amounts of cash balances (Opler et al. 1999), negating the static trade off model where the top management is always on a move to increase the shareholders reserves. The primary motives of holding cash (Bates, 2009) have been the transaction motive, the precautionary motive, the tax motive and the agency motive. The main fact behind developing the transaction motive was to reduce the cost of liquidating assets than holding cash at the time of urgency. Precautionary motive deals with the desire to keep extra money in case an unforeseen situation require a capital outlay (Keynes, 1936). Main objective behind the development of tax motive was the high taxes companies have to pay (Foley et.al., 2007). Majority of the companies don't have cash at the time of tax payment. For this reason companies in the end face the need to liquidate their assets. The last motive is Agency motive. Jensen (1986) discussed that skilled managers try to hold back cash rather than paying it to the owners/shareholders when they have poor investing opportunities. For operations of the firms to run smoothly optimum level of liquidity within the firm should be maintained. Policies regarding working capital requirements, capital structure, dividend payments, cash flow management, investment and asset management characterizes the level of cash a firm maintains (Opler et al. 1999). The notion of determining cash holdings and its evolution is explained with the help of three cash holding theories which are of importance to predict its determinants and policies.

\section{Trade off theory}

The theory primarily deals with two concepts; the cost of holding cash and the benefit you get from holding that cash for maintaining an optimum amount of cash. The cost of investing in the liquid assets is the opportunity cost which the companies forego when they accumulate cash (Ferreira and Vilela 2004).

\subsection{Pecking Order theory}

Myers \& Majluf (1984) presented the theory and discussed that financing basically comes from three sources: firstly retained earnings is considered, then comes the debt and lastly when no other option is left equity is issued which is the last resort.

\subsection{Agency theory}

This theory is presented by Jensen (1986). This theory deals with the relationship of top executives (major shareholders) who delegate authority and the agents (managers) who had to perform those duties delegated to them. Two main problems are tried to be discussed and resolved in this theory. First is that goals achieved by managers are in accordance to the assigned goals (agency problem). Second problem is that the top management and agents try to reconcile their differences in order to increase shareholders wealth and company profits. 
Moreover in addition to the above discussed cash holding theories the major determinants of cash holdings that are of particular interest for this study includes but are not limited to; the size of the firm, leverage, net working capital, sales growth and cash conversion cycle. Earlier literature supports that the smaller firms tend to hold more cash as compared to the companies which have higher capital expenditures, high debt ratios and higher cash substitutes. Likewise the capital structure decisions, liquidity management decisions and sales growth also tend to affect cash holdings of a company. The present study will analyze the affect of these different variables on cash holdings. Pakistan is an emerging economy. Some of the sectors though well developed yet some sectors are still in the phases of development, therefore for this reason all the sectors needed to be studied. The study aims to contribute useful insights and information that may help in determining the affect of different variables on cash holdings for future investment and growth opportunities of corporate sector companies of Pakistan.

\section{Literature Review}

Afza (2007) studied corporate cash holdings of non-financial Pakistani firms from 1985-2005. He study took different factors like cash flow uncertainty, dividend payments, firm size, growth opportunities, leverage and net working capital. The impact of these factors is normally analyzed with the help of Jensen's free cash flow theory, pecking order theory and trade-off Model. Ahmad \& Raza (2012) studied the correlation between cash conversion cycle, size and profitability. The sample selected considered firms from four manufacturing sectors that were listed on Karachi stock exchange. Significant and negative correlation was found between the firm size and time-span of cash conversion cycle and profitability in relation to the total assets. In terms of return on assets, a positively significant relation is found between them. Almeida et.al (2002) presented a theory of corporate liquidity management, predicting that the firms with financial distress generally accumulate more cash in the form of liquid assets considering the dividends, hedging policies and borrowing procedures as compared to the firms with less financial distress. Shah (2012) studied the factors affecting cash holdings of Canadian corporate organizations. Sample of 166 firms listed on Toronto Stock Exchange from 2008-2010 was selected. The outcomes were that the cash flow, board size, firm size, leverage, market to book and net working capital notably affect the cash holdings of Canadian firms. The results are handy for the financial management consultants, financial managers and investors.

Bates et al. (2009) determined the fact that the U.S firms average cash ratio doubled from 1980 to 2006. The importance of it can be realized through the fact that with the help of these cash holdings firms retire their debt obligations. They found a relation that higher the riskiness of cash flows, higher is the cash ratios. They found no evidence leading to the fact that an agency conflict leads to an increase in the cash balances. Benjamin \& Samuel (2012) studied the linkage between bank cash holdings and the net working capital by collecting data sample from 1999-2008 of Ghana listed companies. The random effects technique was used for the analysis of findings. He determined that profitability was significantly and positively related with cash holdings. Different characteristics like bank size, capital, cash conversion cycle and collection period of debtors have negatively significant relationship with cash holdings of banks. Olivier (1994) studied the fact that when firms receive cash totally unexpected calling it as a cash windfall, then what do they do with it. They examined eleven such firms who won cash by winning some cases or settlement of their law suits. They found that some of the firms did not took the opportunity of investing in growth opportunities and in the end face acquisitions by other large firms. They also studied the managerial behaviour regarding the long run profitability and survival of firms.

Ozkan (2004) studied the factors affecting cash holdings of corporate organizations in context to the managerial ownership. Their main focus was to study the managerial authority of delegating powers including the board structure of UK firms. Their results determined the fact that bank debt, liquid assets, cash flows, leverage and growth opportunities are important in shaping cash holdings of the firm. Dittmar (2007) investigated that corporate governance has an impact on the value of firm. They determined the differences of cash holdings of the poor governed and the well governed firms. They determined the fact that firms having higher corporate governance level generally have high cash reserves as against the firms with lower level of corporate governance. Agency costs also arise due to low corporate governance. Faulkender (2002) determined the effects of different firm characteristics on cash holdings of small companies. It was found that firms holding high levels of cash and face information asymmetry, agency problems and having high debt ratios. Firms having low level of these firm characteristics hold low level of cash balances. Another important finding was that taxes don't have an impact on cash holdings as compared to managerial ownership. Lastly the study determined that cash balances decrease with the size of firm.

Ferreira \& Vilela (2004) examined the factors affecting level of cash holdings of corporate organizations. The study discussed the fact that negative relation exists with bank debt. This is the reason why companies prefer to have lower level of cash with them. The study also found that firms in countries with centralized business systems and protection of rights of investors tend to hold lower levels of cash. Significant 
relation between cash holdings and different variables also exist. Foley et al. (2007) studied the fact the majority of the U.S firms are in a need to liquidate their assets due to the high tax costs. So to avoid this situation of paying taxes on their repatriating income, firms tend to hold cash than to liquidate their assets. They found that firms having high repatriating taxes hold their cash abroad than companies having low repatriating tax burdens. Another fact discussed was the dividend taxation, which are the taxes applied on the dividend given to the shareholders. Harford et.al (2008) found that firms that have low cash in the form of savings have weaker corporate governance. It was found that when distributing dividends to shareholders weaker firms repurchase those dividends. Another important fact was determined that unskilled U.S managers reduce their cash reserves without any need rather than hoarding it. They carry out unnecessary capital expenditures and acquisitions of non profitable firms lowering the cash balances.

Hoffman (2006) studied the determinants of corporate cash holdings and emphasized the important corporate cash holdings determinants of New Zealand's firms. The study found availability of liquid asset substitutes, growth opportunities, cash flow variability, leverage and payment of shareholder dividends as significant determinants of corporate cash holdings. High growth opportunities and high cash flow variability lead to an increase in the cash holdings. It was also found that cash holdings get lower due to the payment of shareholders dividends and liquid asset substitute. Jani et.al (2004) explored cash holdings of Swiss firms mainly because of their popularity for hoarding high levels of cash balances and having a centralized ownership structure. It was found that the rights of minority shareholders are poorly safeguarded. Different firm characteristics like voting rights of shareholders, growth and investment opportunities were studied in relation to cash holdings. The results depicted the fact that firms which are less centralized, having simple voting right shares adjust easily and hold more cash. Kim et al. (1998) discussed the fact of investing in liquid assets when financing from external sources is unbearable of U.S firms. Level of liquidity which is beneficial for a firm can be determined by comparing the differences of the lower returns on liquid assets and the advantages earned on attenuating the external financing needs.

Daher (2010) studied in detail the factors affecting the cash holdings by taking data sample from public and private firms (more than 60,000 firms), covering period 1985- 2005. The major findings include that an increasing cash holding ratio specifically of private firms, almost double between 1994 and 2005. They mainly focused on the linkage between cash holding and different features of firm. Negative and significant relation was found between cash and different variables including net working capital, firm size, leverage, capital expenditures and cash flows. Lawrencia et.al (2012) studied relationship of cash holdings and its variables of Nigerian firms. Applying the co-relational test it was determined that net working capital; cash flow, profitability, leverage and investment opportunities affect the corporate cash holdings in a significant way. The important finding was that no relationship was found with size of firm and growth opportunities. Opler et al. (1999) studied the factors affecting the corporate cash holdings of public listed companies from U.S. Through the application of different tests the study found that firms having higher growth prospects, variable and riskier cash flows generally have higher cash holding ratios. Firms having higher investment prospects in capital market and high credit ratings hold low level of cash as compared to non cash assets then companies with less investment opportunities. Sohani (2012) determined variables that have a strong impact on the cash holding decisions by considering manufacturing firms of Bangladesh. Regression analysis was conducted to generalize the results. The results showed that apart from other variables net working capital, volatility of cash and Tobin's $\mathrm{Q}$ has a significant relation with the cash holdings of firms.

On the basis of the review of the earlier studies above, it may be derived that a relationship exists between cash holdings and different firm characteristics like, size of firm, corporate governance, board structure, voting rights \& policies etc. Widely held researches established that cash holdings are affected by leverage, net working capital, investment opportunity and firm size. Cash ratios become high if cash flow riskiness and growth opportunities are also high. Firms having low corporate governance hold high level of cash holdings. Financial analysts and managers need to be more specific regarding the functionality of cash determining systems. The geographical and socio economic factors affect the level of cash, altering the behaviour of different firm characteristics. Majority of the researches does not provide any insight regarding the developing or under developed countries.

\section{Methodology}

Keeping in view the results of earlier findings based on different models and techniques, the present study will add to the existing literature by examining the determinants of corporate cash holdings of non financial listed companies belonging to all of the sectors of Pakistani companies listed at Karachi stock exchange. 


\subsection{Determinants of Cash Holdings}

The literature permits to take the following determinants of cash holdings and develop testable hypotheses accordingly

\subsubsection{Firm size (SZ)}

Trade off theory predicts inverse relationship between the firm size and the cash holdings, because large firms tend to invest in different growth opportunities instead of stockpiling it (Harris and Raviv, 1990). But Pecking's order theory predicts a positive relation. This is so because majority of the large firms perform better and for this they need to have cash in hand, instead of liquidating their assets (Opler et al., 1999). So, firm size also affects the liquidity levels. Ferreira \& Vilela (2004) also predicted an inverse relationship between the variables. Firm size is calculated by taking natural $\log$ of total assets of any specific firm. So an inverse relationship is expected between cash and firm size. On the basis of above discussion following hypothesis may be developed.

H1: Firm size is inversely related to cash holdings.

\subsubsection{Net working capital (NWC)}

According to the trade off theory an inverse association exists between cash and net working capital. This is so because net working capital majorly consists of liquid asset cash substitutes. So at a specific period of time a firm can only maintain high levels of cash or liquid assets. Previous researchers like Bates et al. (2009), Ferreira \& Vilela (2003) and Opler et al. (1999) also predicted the existence of same relationship. Therefore an inverse relationship is expected between NWC and cash holdings hence the following hypothesis may be developed.

H2: Net Working Capital is inversely related to cash holdings.

\subsubsection{Leverage $(\mathrm{LV})$}

An inverse association between leverage and cash holdings is predicted by the trade-off and the pecking order theory. According to Opler et al. (1999) firm having high debt ratios have low cash reserves because they have to pay out their constraining outstanding debts. In this way leverage can be reduced. Bates et al. (2009) and Ferreira \& Vilela (2003) also predicted the inverse association between the variables. So an inverse relationship can be predicted and the following hypothesis may be developed.

H3: Leverage is inversely related to cash holdings.

\subsubsection{Cash Conversion Cycle (CCC)}

It can be basically described as the days between the disbursement and collection of cash involving different set of activities. CCC is considered to be efficient and beneficial when the firms receive cash from their debtors before they have to pay to their creditors (Hutchison et.al, 2007; Uyar, 2009; Ahmed, 2012). A negative $\mathrm{CCC}$ exists when the management gets cash from its accounts receivables before liquidating its assets. Hence an inverse relationship is predicted between CCC and cash holdings and the following hypothesis may be developed.

H4: CCC is inversely related to cash holdings.

\subsubsection{Sales Growth (SG)}

Since the sales growth involves the economies of scale therefore huge amount of inventory needs to be kept in stock to increase the sales growth. Moreover increasing accounts receivable also supports increasing sales growth. As sales growth increase, opportunities to invest in different operations also increase. According to Bates et al., (2009) firms having higher investment opportunities cannot take the risk of being financially constrained. So an inverse relationship is predicted between sales growth and cash holdings. Therefore following hypothesis can be developed.

H5: Sales Growth is inversely related to cash holdings.

The above discussion of variables on the basis of review of literature and the predicted relationships for the present study are summarised below in table 3.1.

Table 3.1

\begin{tabular}{|c|r|r|r|r|}
\hline Variable & $\begin{array}{c}\text { Trade off } \\
\text { Theory }\end{array}$ & $\begin{array}{c}\text { Pecking Order } \\
\text { Theory }\end{array}$ & $\begin{array}{c}\text { Agency } \\
\text { Theory }\end{array}$ & Predicted \\
\hline SZ & Negative & Positive & Positive & Negative \\
\hline NWC & Negative & - & - & Negative \\
\hline LV & Negative & Negative & - & Negative \\
\hline CCC & Unknown & Unknown & Unknown & Negative \\
\hline SG & Positive & Positive & Negative & Negative \\
\hline
\end{tabular}


The following theoretical model is derived for testing:

$\mathrm{CB}=\alpha-\beta_{1} * \mathrm{SZ}-\beta_{2} * \mathrm{NWC}-\beta_{3} * \mathrm{LV}-\beta_{4} * \mathrm{CCC}-\beta_{5} * \mathrm{SG}+\varepsilon$

Where:

$\alpha=$ constant value

$\beta=$ beta coefficient

$\varepsilon=$ error term

$\mathrm{CB}=$ cash holdings of firms

$\mathrm{SZ}=$ size of firms

NWC $=$ net working capital of firms

$\mathrm{LV}=$ leverage of firms

$\mathrm{CCC}=$ cash conversion cycle of firms

$\mathrm{SG}=$ sales growth of firms

\subsection{Population and Sampling}

The population of the study is the non financial Pakistani firms listed on the Karachi stock exchange (KSE). There are 441 companies. The sample included 395 firms from all sectors. The study excluded some of the companies due to huge amount of missing observations due to the non availability of data of defaulter companies. So the selected sample well represents almost the entire population.

\subsection{Data Collection}

The secondary data for this study was taken from the financial statement analysis of non financial companies, listed on Karachi stock exchange (KSE) issued by the State Bank of Pakistan (SBP). The data set has been taken from the years 2005 to 2011 .

\subsection{Data Analysis}

The Pearson correlation and multiple regression analysis were used to conduct data analysis. ANOVA was also applied to check the degree of variance between the dependent and independent variables.

\subsection{Descriptive Statistics}

\section{Analysis \& Discussion}

Descriptive statistics have been applied to the collected data to know the descriptive properties of data. Results are shown in table 4.1 below.

Table 4.1

\begin{tabular}{|c|c|r|r|r|r|r|}
\hline Variables & No. of Obs. & \multicolumn{1}{|c|}{ Mean } & Median & \multicolumn{1}{c|}{ Std. Dev. } & \multicolumn{1}{c|}{ Kurtosis } & \multicolumn{1}{c|}{ Skewness } \\
\hline CB & 2370 & 0.09 & 9.69 & 3.13 & 1.11 & -0.65 \\
\hline SZ & 2370 & 13.98 & 14.26 & 2.96 & 10.70 & -2.73 \\
\hline NWC & 2370 & -1.00 & -0.83 & 0.83 & 11.13 & -2.50 \\
\hline LV & 2370 & -0.43 & -0.37 & 0.78 & 20.83 & 0.35 \\
\hline CCC & 2370 & 3.78 & 4.10 & 1.80 & 1.08 & -0.59 \\
\hline SG & 2370 & 0.03 & 2.94 & 1.51 & 0.46 & -0.52 \\
\hline
\end{tabular}

The above table provides information regarding mean, median, standard deviation, skewness and kurtosis of the different variables of the study. The statistics tell that the data is negatively skewed for CB, SZ, NWC, CCC and SG whereas positively skewed for LV. This tells that most of the firms will be having higher than mean values for negatively skewed variables and lower than mean values for positively skewed variables. For such data median value is a better indicator of average statistics. High standard deviation reflects the tendency of data to lie far from mean values.

\subsection{Pearson Correlation}

Pearson correlation is applied to test the relationship between the studied variables and to test for the multicollinearity among variables; the results are given below in table 4.2

Table 4.2

\begin{tabular}{|c|l|l|l|l|l|l|}
\hline CB & 1 & & & & & \\
\hline SZ & 0.80 & 1 & & & & \\
\hline NWC & 0.08 & -0.11 & 1 & & & \\
\hline LV & -0.24 & -0.25 & -0.07 & 1 & & \\
\hline CCC & 0.29 & 0.39 & 0.02 & -0.11 & 1 & \\
\hline SG & 0.25 & 0.31 & 0.06 & -0.11 & 0.30 & 1 \\
\hline
\end{tabular}


Pearson correlation results imply that negative and significant correlation exists between cash holdings and leverage whereas positive and significant correlation exists between cash holdings, size of firm, net working capital, cash conversion cycle and sales growth. Weakest correlation exists between net working capital and cash holdings whereas strongest correlation exists between size and cash holdings. Moreover the above table show that there is no serious multicollinearity issue.

\subsection{Multiple Regression Analysis}

Multiple regression analysis is applied to the data to measure the impact of independent variables on dependent variables. The results are shown below in table 4.3

Table 4.3

\begin{tabular}{|c|c|c|c|c|}
\hline & Coefficients & Standard Error & t-stat & P-value \\
\hline Intercept & -1.7861 & 0.1830 & -9.7613 & 0.0000 \\
\hline SZ & 0.8738 & 0.0144 & 60.4734 & 0.0000 \\
\hline NWC & 0.6442 & 0.0457 & 14.0884 & 0.0000 \\
\hline LV & -0.1046 & 0.0493 & -2.1219 & 0.0339 \\
\hline CCC & -0.0497 & 0.0228 & -2.1790 & 0.0294 \\
\hline SG & -0.0344 & 0.02658 & -1.2945 & 0.1956 \\
\hline
\end{tabular}

The above table tells that except SG all the other variables are significant predictors of CB. The predicted relationships are observed to be true for LV, CCC and SG whereas opposite relationships are observed in SZ and NWC. The observed relationships can be mathematically expressed as:

$\mathrm{CB}=-1.79+0.87 * \mathrm{SZ}+0.64 * \mathrm{NWC}-0.10 * \mathrm{LV}-0.04 * \mathrm{CCC}-0.03 * \mathrm{SG}+0.18$

On the basis of above analysis $\mathrm{H} 1$ and $\mathrm{H} 2$ stand rejected due to opposite relationship observed though significant. $\mathrm{H} 3$ and $\mathrm{H} 4$ are accepted being the actual relationship found was as per prediction. H5 is rejected being insignificant predictor though negatively linked as predicted.

Table 4.4

\begin{tabular}{|l|c|c|c|c|c|}
\hline & \multicolumn{1}{|c|}{ df } & \multicolumn{1}{c|}{ SS } & \multicolumn{1}{c|}{ MS } & F & Prob \\
\hline Regression & 5 & 15517.83 & 3103.56 & 951.08 & 0.0000 \\
\hline Residual & 2364 & 7714.22 & 3.26 & & \\
\hline Total & 2369 & 23232.05 & & & \\
\hline
\end{tabular}

The above table tells the variation due to studied variables and the residual effect not explained by this model. It tells that the regression and the residual sums are significantly different and the significance of $\mathrm{F}$ statistics tells the overall goodness of the model.

Table 4.5

\begin{tabular}{|l|l|l|l|l|}
\hline Multiple R & R Square & Adjusted R & Standard Error & Observations \\
\hline 0.8173 & 0.6679 & 0.6672 & 1.8064 & 2370 \\
\hline
\end{tabular}

The adjusted $\mathrm{R}^{2}$ value portray that almost $67 \%$ variation in cash holdings is explained by the changes in the studied variables size of firm, sales growth, cash conversion cycle, leverage and net working capital.

The above analysis identify that size of firm has a highly significant relationship with cash holdings and an increase in size of firms leads to higher cash balances therefore larger firms tend to have higher cash balances as against smaller firms. Moreover net working capital also has a highly significant relationship with cash holdings and an increase in net working capital leads to higher cash balances therefore highly liquid firms tend to have higher cash balances as against lesser liquid firms. Leverage has a highly significant relationship with cash holdings and an increase debt financing leads to lower cash balances therefore higher debt financed firms tend to have lower cash balances as against lesser debt financed companies with higher cash balances. Cash conversion cycle has a highly significant relationship with cash holdings and an increase in cycle leads to lower cash balances therefore larger cycle companies tend to have lower cash balances as against smaller cycle companies with higher cash balances. Sales growth has no significant relationship with cash balances of companies hence the rate of growth have no impact on cash holdings.

\section{Conclusion}

The study concludes that the major determinants of cash holdings in Pakistani listed non financial companies are size of firms, leverage, net working capital and cash conversion cycle. Sales growth has no linkage with cash holdings of companies. The variability of cash holdings due to the changes in the studied variables is different. The results of the study supported the findings of different theories presented in literature. 
It is determined that almost $67 \%$ of variation in cash holdings is due to the variables having significant relationship with it. The remaining $34 \%$ variation is due to unknown factors not accounted for in this study. The results of the study confirmed the earlier findings that levels of cash are less in firms having high ownership concentration structure and because of this less agency problems arise. The negative association between cash holdings and firm size may be due to the economies of scale. Moreover information asymmetry along with the issue of problem in getting external financing may be the reasons in case of larger firms. As far as cash conversion cycle is concerned quite a lesser studies have been conducted so far to explore its impact on cash holdings, since none of the well known theories explained any relationship between cash conversion cycle and cash holdings.

\section{References}

[1] Afza, T., \& Adnan, S.M. (2007). Determinants of corporate cash holdings: A case study of Pakistan. Proceedings of Singapore Economic Review Conference (SERC) 2007, August 01-04, Organized by Singapore Economics Review and the University of Manchester (Brooks World Poverty Institute), Singapore 164-165. [Online] Available: [https://editorialexpress.com/cgibin/conference/download.cgi?db_name=SERC2007\&paper_id=166], (October 20, 2011)

[2] Ahmed, M., Raza, K., (2012 ) "The Optimal Relationship of Cash Conversion Cycle with Firm Size and Profitability" International Journal of Academic Research in Business and Social Sciences, Vol. 2, No. 4

[3] Almeida, H., Campello, M. and Weisbach, M. (2002). "The Demand for Corporate Liquidity: A Theory and Some Evidence" Working Paper, University of Illinois and New York University

[4] Amarjit G., Charul S., (2012). "Determinants of Corporate Cash Holdings: Evidence from Canada" International Journal of Economics and Finance Vol. 4, No. 1

[5] Bates, T., Kahle, K. and Stulz R., (2009). "Why do U.S. Firms hold so much more Cash than they used to?" The Journal of Finance. Vol. LXIV, No. 5

[6] Benjamin, Y., Samuel K., (2012). "Working Capital Management and Cash Holdings of Banks in Ghana" European Journal of Business and Management Vol. 4, No.13,

[7] Blanchard, O., Lopez-de-Silanes, F., Shleifer, A., (1994). "What do firms do with cash?” Journal of Financial Economics 36, 337360 .

[8] Caglayan-Ozkan, N. and A. Ozkan (2004). "Corporate Cash Holdings: An Investigation of U.K. companies". Journal of Banking \& Finance 28, 2103-2134

[9] Dittmar, A., and J. Mahrt-Smith, (2007). "Corporate Governance and the Value of Cash Holdings," Journal of Financial Economics, 83, 599-634.

[10] Faulkender, M. (2002) "Cash Holdings among Small Business", Working Paper (Kellogg School of Management, Northwestern University)

[11] Ferreira, M. and A. Vilela (2004). "Why Do Firms Hold Cash? Evidence from EMU Countries". European Financial Management, Volume 10, Issue 2, 295-319, June.

[12] Foley, C., Hartzell, J., Titman, S. and G. J. Twite (2007). "Why Do Firms Hold So Much Cash? A Tax-Based Explanation”. Journal of Financial Economics 86, 579-607.

[13] Harford, J., Mansi, S. and W. Maxwell (2008). "Corporate Governance and a Firm's Cash Holdings". Journal of Financial Economics 87, 535-555

[14] Harris, M. and A. Raviv (1990). "Capital Structure and the Informational Role of Debt”. Journal of Finance, Vol. 45, pp. 321 -49.

[15] Hofmann, C., (2006). "Why New Zealand Companies hold cash: An empirical Analysis" Unpublished Thesis.

[16] Hutchison, P. D., Farris II, M. T. and Anders, S. B., (2007). "Cash-to-cash analysis and management", The CPA Journal, Vol. 77 No. 8, pp. 42-47.

[17] Jani, E., Hoesli, M. and A, Bender., (2004). "Corporate Cash Holdings and Agency Conflicts". Working Paper.

[18] Kim, C. S., Mauer, D.C. and A. E. Sherman (1998). "The Determinants of Corporate Liquidity: Theory and Evidence". Journal of Financial and Quantitative Analysis 33, 305-334.

[19] Mai Daher (2010). "The Determinants of Cash Holdings in UK Public and Private Firms". Dissertation (Lancaster University Management School, Lancaster University)

[20] Myers, S., and N. Majluf (1984). "Corporate Financing and Investment Decisions When Firms Have Information that Investors Do Not Have". Journal of Financial Economics 13, 187-221.

[21] Olatunde, L., Ogundipe, S, E., and Kehinde A, S., (2012). "Cash Holding and Firm Characteristics: Evidence from Nigerian Emerging Market”. Journal of Business, Economics \& Finance, Vol. 1, No 2.

[22] Opler, T., Pinkowitz, L., Stulz, R. and R. Williamson (1999). "The Determinants and Implications of Corporate Cash Holdings". Journal of Financial Economics 52, 3-46.

[23] Sohani Islam, (2012) “Manufacturing Firms' Cash Holding Determinants: Evidence from Bangladesh" International Journal of Business and Management Vol. 7, No 6.

[24] Uyar, A. (2009). The Relationship of Cash Conversion Cycle with Firm Size and Profitability: An Empirical Investigation in Turkey. International Research Journal of Finance and Economics ISSN 1450-2887 Issue 24 (2009) 